\title{
Physician-assisted death and the changing face of geriatric medicine
}

\author{
Matthew Douglas-Vail (Meds 2018), Keegan Guidolin (Meds 2017) \\ Faculty Reviewer: Dr Raza M Navqi, MD, FRCPC (Division of Geriatric Medicine)
}

\section{INTRODUCTION}

On February 6th, the Supreme Court of Canada ruled that the century-old law condemning assisted suicide was unconstitutional. This momentous ruling now opens the door for physician-assisted suicide. ${ }^{1}$ This decision has left many wondering how this will affect geriatric, palliative, and end-of-life care in Canada. The ruling has been met with much controversy, leaving both physicians, and the public unsure how to apply these new rulings to everyday medicine. The terms "euthanasia" and "physician-assisted suicide" (or some variant thereof) have been used to describe the potential consequences of the ruling in the media, though these terms should not be obfuscated. These are two distinct acts, though this ruling makes both permissible. Materstvedt et al defined physician-assisted suicide as "a doctor intentionally helping a person to commit suicide by providing drugs for self-administration, at that person's voluntary and competent request." ${ }^{2}$ Conversely, euthanasia is outlined as "a doctor intentionally killing a person by the administration of drugs, at that person's voluntary and competent request."2

\section{HISTORY OF PHYSICIAN-ASSISTED DEATH}

Prior to the Supreme Court ruling, the role of Canadian physicians in assisted suicide was clear. Criminal Code of Canada section 241(b) states "everyone who [...] (b) aids or abets a person to commit suicide, whether suicide ensues or not, is guilty of an indictable offence and is liable for imprisonment for a term not exceeding fourteen years." ${ }^{3}$ The ethics surrounding physician-assisted suicide, however, are less clear. Many physicians currently employ the principle of double effect when taking care of palliative patients. In essence, double effect is the administration of any medication, often narcotics or sedatives, with the intent to palliate dying patients even though the administration of these drugs may hasten death. Interestingly, in places where physician-assisted suicide is forbidden, a "medical death" hastened by palliation is typically permissible. ${ }^{4}$ It is the intention that is most important in these cases as the physician is not intending to end life but rather chooses to focus on patient comfort at the expense of known drug side effects.

Physician-assisted suicide is inextricably linked to geriatric care. In 1997, Oregon legalized physician-assisted suicide. In the first year of legal physician-assisted suicide, the median age of physician-assisted suicide patients was 69 , well within the jurisdiction of geriatrics. ${ }^{5}$ Of these patients, $86 \%$ had cancer, $21 \%$ were completely disabled, and all were terminally ill. A survey in the Netherlands also found that physician-assisted suicide occurred predominantly in elderly populations, with a median age of 71 .
Surveys have also shown that elderly people would choose to undergo physician-assisted suicide to prevent becoming a burden to their families or others. These patients were quoted as saying, "I wouldn't want to become a nuisance under any circumstance." This provides some qualitative insight into why some healthy older individuals might support medical practices that hasten death. In the Netherlands, roughly $17 \%$ of patients request physician-assisted suicide because they are "tired of living" and $25 \%$ of those had no serious disease or no disease at all. ${ }^{6}$

Opinions on physician-assisted suicide are divided among physicians themselves. Many physicians believe that patients have a right to die with dignity, or that patients have a fundamental right to autonomy over their bodies. They may also want to help to alleviate the suffering endured by their patients with intractable or terminal diseases. Conversely, many physicians see physician-assisted suicide as a sign that current palliative care is inadequate. They may also believe that physicians should not take on the role of executioner. In addition, there is significant concern about the potential for abuse of power by physicians.

\section{THE SUPREME COURT RULING}

The Supreme Court ruling has profoundly altered the landscape of physician-assisted suicide. The court ruled "prohibition of physician-assisted dying infringes on the right to life, liberty and the security of the person." The ruling states that adults who are enduring intolerable suffering can consent to ending their own lives. The court found that a person's response to an irremediable medical condition was a matter of dignity and autonomy. As well, "by leaving people [...] to endure intolerable suffering, it impinges on their security of the person." The court also highlighted the fact that in jurisdictions that have legislated physician-assisted suicide such as Oregon and the Netherlands, the safeguards put in place have been effective. In an unusual move, all 9 justices shared credit for the ruling, a move intended to lend institutional weight to the ruling. Technically, the court has given the federal government 12 months to write legislation to respond to, or attempt to overturn, the ruling. If legislation is not put forth, physician-assisted suicide will be in a situation similar to that in which abortion resides: legal and left to the medical profession to regulate without government oversight. ${ }^{1}$

The ruling is not limited to those who might require assistance to end their lives, for example patients suffering from amyotrophic lateral sclerosis (ALS). It is unclear whether an intractable psychiatric condition might qualify as an "irremediable medical con- 
dition", since psychological pain has not been addressed directly. Instead, it is left up to physicians and lawmakers to determine what qualifies as "enduring and intolerable suffering." Under the new ruling, physicians are not compelled or required to help patients end their lives, it merely removes prohibitions against it. ${ }^{1}$ The Canadian Medical Association (CMA) is presently encouraging physicians to "follow their conscience" when making these decisions.7

\section{THE ROLE OF THE CMA}

The CMA has been bracing itself for this decision. For a year and a half, the organization has been debating and researching how to best handle physician-assisted suicide. As the president of the CMA, Dr Chris Simpson acknowledges physician-assisted suicide requires physicians to make decisions that go to the "very gut of one's personal ethics and morals." ${ }^{8}$ The CMA organized town halls and reviewed physician-assisted suicide practices in other countries, most notably Oregon and the Netherlands. In August 2014 at the CMA's annual general meeting, members voted 91\% in favour of a motion to allow physicians "to follow their conscience when deciding whether to provide medical aid in dying." Although this is not a formal regulation, it speaks to the general consensus of physicians' opinions on physician-assisted suicide regulations. This resolution also signals a changing of policy for the CMA, an organization historically opposed to both euthanasia and physician-assisted suicide.

\section{THE CHANGING ROLE OF THE GERIATRICIAN}

The emphasis on quality of life in end-of-life care and advanced planning discussions suggest that geriatricians will be at the center of the physician-assisted suicide discussion. Geriatricians focus on holistic, person-centered care, which often centers on quality of life rather than its duration. Geriatricians often decrease pill burden in patients who would rather take fewer medications, even at the expense of living for a shorter time, for the sake of fewer side effects. ${ }^{6}$

With the emphasis on holistic care and quality of life, physician-assisted suicide is well within the realm of geriatric medicine. The question remains however, how will this new ruling change the role of these physicians? It could theoretically alter the landscape of the principle of double effect. This ruling may require geriatricians to discuss the option of physician-assisted suicide with their patients suffering from irremediable medical conditions. As well, physicians will potentially have to engage the families and the substitute decision makers of their patients, an unquestionably difficult conversation.

On a personal level, this will require geriatricians to grapple with their own moral and ethical opinions surrounding physician-assisted suicide. In a 2014 survey, only $27 \%$ of physicians reported that they would be "likely or very likely to participate in" physician-assisted dying. To that point, many provincial regulatory colleges (in Ontario, the College of Physicians and Surgeons of Ontario) require that physicians refer their patients to another doctor if they refuse to offer controversial treatments. Historically, these treatments have included prescribing birth control and performing abortions. This list may now require expansion to include physician-assisted suicide. As Dr James Downar, a palliative care physician, explains, "we need to recognize that conscientious objection in this context can serve as a barrier and we need a very robust system to make sure that the physician's right to conscientious objection does not impinge on the patient's right to receive

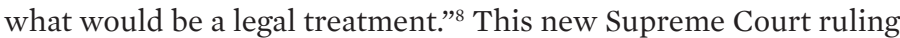
will profoundly alter the practice and culture of geriatric medicine.

\section{CONCLUSIONS}

The Supreme Court ruling declared that aspects of the Criminal Code were unconstitutional with respect to physician-assisted suicide. Prior to this ruling, the role of physicians in these cases was clear: they could not participate. With this new ruling, however, the landscape has changed. Physician-assisted suicide is closely linked to geriatric medicine, as we have seen in Oregon and the Netherlands. This new ruling may require that geriatricians discuss physician-assisted suicide as an option with their patients. It will certainly require geriatricians to reflect on their own beliefs surrounding physician-assisted suicide. This new ruling will reshape the practice of geriatric medicine in Canada.

\section{REFERENCES}

1. Carter v. Canada (Attorney General), 2015 SCC 5.

2. Matersvedt, LJ, Clark D, Ellershaw K. Euthanasia and physician-assisted suicide: a view from an EAPC Ethics Task Force. Palliative Med. 2003 Apr;17(1):97-101.

3. Criminal Code, R.S.C., c. C-46 (1985).

4. Quill E, Battin, MP. Physician-assisted dying. Baltimore (MD): Johns Hopkins University Press; 2004. 194 p.

5. Kirk K. How Oregon's Death with Dignity Act affects practice. The American Journal of Nursing. 1998 Sept:98(1):54-5.

6. Finlay IG, George R. Legal physician-assisted suicide in Oregon and The Netherlands: evidence concerning the impact on patients in vulnerable groups-another perspective on Oregon's data. J Med Ethics;37(2011):171-4.

7. The Canadian Medical Association [Internet]. Ottawa (ON): Canadian Medical Association; 2014. Euthanasia and assisted death. Available from: https://www.cma.ca/Assets/assets-library/document/en/advocacy/EOL/cma-policy-euthanasia-assisted-death-updated-2014-e.pdf

8. Globe and Mail [Internet]. Toronto (ON): Globe and Mail; 2015. Canadian doctors drafting new rules in case doors open to assisted suicide 2015 Feb 6. [cited 2015 Apr 21]. Available from: http://www.theglobeandmail.com/news/national/canadian-doctors-drafting-new-rules-incase-doors-open-to-assisted-suicide/article22798448/

9. The Canadian Medical Association [Internet]. Ottawa (ON): Canadian Medical Association; 2014. Reports to General Council. Available from: https://www.cma.ca/Assets/assets-library/document/en/aboutus/2014-Reports-to-GC.pdf 